\title{
The Effectiveness of Physical Education in Elementary Schools Assessed from the Physical Fitness and Obesities of Elementary School Students
}

\author{
I Ketut Yoda \\ Sport Science Department \\ Universitas Pendidikan Ganesha, Singaraja Bali, Indonesia \\ yodaketut@undiksha.ac.id
}

\author{
Gede Doddy Tisna MS \\ Sport Science Department \\ Universitas Pendidikan Ganesha, Singaraja Bali, Indonesia
}

\begin{abstract}
The objectives to be achieved in this study are: (1) to describe the level of physical fitness of elementary school students in Buleleng District, Buleleng Regency, Bali, and (2) to describe the obesity level of elementary school students in Buleleng District, Buleleng Regency, Bali. The population in this study were elementary school students of Class V Buleleng District, Buleleng Regency, Bali. A total sample of 120 students was taken by random sampling technique. The data collection technique used is the method of observation, documentation study, and tests. Based on the analysis, the following results were obtained: 1) as much as $\mathbf{2 . 5 \%}$ of the students' physical fitness levels were in the very poor category; 2) as much as $37.5 \%$ of the students' physical fitness levels are in the low category; 3) as much as $41.67 \%$ of the students' physical fitness levels are in the medium category; 4) as much as $15.83 \%$ of the students' physical fitness levels are in the good category; 5) as much as 3 people or $2.5 \%$ of the students' physical fitness levels are in the very good category. The student body mass index was obtained: 1 ) as much as $44.17 \%$ in the weight category thin; 2) $\mathbf{2 6 . 6 7 \%}$ are in the light category thin; and only 3) $1.67 \%$ are in the normal category; and 4) $27.5 \%$ are in the overweight category. From these results, it can be concluded that the physical education learning process in Buleleng District Elementary School is not yet effective.
\end{abstract}

Keywords - physical education, Physical Fitness, Obesity

\section{INTRODUCTION}

Physical education is basically an integral part of the education system as a whole. Therefore, the implementation of physical education must be directed at the limits of these goals. The goal of physical education is not only to develop the physical realm, but also to develop all the potential of students. Physical education as an integral part of the education system as a whole has an important role in achieving the goals of national education. Physical education is an integral part of total education that achieves the goal of developing physical, mental, social, and emotional fitness for society, by means of physical activity $[1,2]$.

As part of education, what can be achieved by physical education must be able to help develop the child's personality in accordance with educational goals, because in essence education seeks to provide opportunities for the development of all aspects of the child's or human's personality so that educational goals must be based on the domain of education. or aspects of the human person.
The role of physical education in schools is very important for the development of body organs in improving physical health and fitness, neuromuscular development, mental-emotional development, social development, and intellectual development. The body is the main foundation in building a healthy generation physically, mentally, socially, and spiritually. Thus in learning physical education the most important thing is how a physical education teacher is able to bring each child to be able to develop both physically, psychomotor, affective, cognitive, and spiritual to the maximum in accordance with the potential of the child

In connection with the importance of physical factors as the main foundation in the development of a healthy human being as a whole, what is often the main indicator in terms of looking at physical health in elementary school-age children is the physical fitness factor and the level of childhood obesity. There is no doubt that physical fitness will greatly affect one's productivity. Physical fitness shows the quality of a person's physiological organs.

When viewed from the level of physical fitness of the Indonesian people based on the 2006 sport development index (SDI) data, it is still very low, namely $37.40 \%$ in the very poor category; $43.90 \%$ less; $13.55 \%$ moderate; $4.07 \%$ good; and only $1.08 \%$ is very good. While, the physical fitness level index of Balinese people has only reached 0.133 [3]. The physical fitness figure of the Balinese people as shown by SDI data is in the low category. Based on the results of observations at two elementary schools in Buleleng Regency by taking 60 samples from fifth grade elementary school children, the results were: (1) 7 people were in the very poor category $(11.7 \%)$; (2) 24 people in the poor category $(40 \%)$; (3) 26 people in the medium category $(43.3 \%)$; (4) 3 people are in good category (5\%). This condition is certainly very concerning for all of us.

Many the phenomenas and research results described that the implementation of physical education, sport and health learning either in elementary school, junior high school, or high school, especially in Buleleng regency- Bali is not optimal [4].

The progress of information and communication technology, namely entering the 4.0 industrial revolution which has reached a very high stage, especially in the midst of the Covid-19 pandemic, learning physical education carried out online further adds to the deterioration of the role of 
physical education in building physical fitness among adolescents and children. A lifestyle that is increasingly away from the spirit of total development, because it prioritizes the excellence of intellectual intelligence, while sacrificing the interests of individual physical and moral excellence. The lack of movement in life culture is therefore increasingly prevalent among children and adolescents, combined with the increasing loss of public spaces and life tasks that require hard physical efforts. Everything becomes easy, so that gradually his physical fitness deteriorates. This is exacerbated by unhealthy and irregular eating patterns that tend to overeat, increasing the chance of increasing weight gain in uncontrolled children and resulting in overweight or obesity

Obesity is a condition where there is accumulation of excess body fat so that a person's weight is far above normal and can endanger health. According to World Health Organization (WHO) Overweight and obesity are defined as abnormal or excessive fat accumulation that presents a risk to health. A body mass index (BMI) over 25 is considered overweight, and over 30 is obese. The issue has grown to epidemic proportions, with over 4 million people dying each year as a result of being overweight or obese in 2017 according to the global burden of disease [5]. Based on the results of Basic Health research in 2013, about $11.9 \%$ of the prevalence rate of obesity occurs in Indonesian children [6]. According to dr. Aman B. Pulungan, $\operatorname{SpA}(\mathrm{K})$, scond chairman Central Board Ikatan Dokter Anak Indonesia (IDAI), the obesity rate in children in Indonesia has reached a terrible figure [7]. From a health perspective, the Indonesian nation is included in the top 10 world category experiencing prevalence Non-Communicable Disease (NCD) including heart coronary disease as first"Silent Killer", overweight and obesity which results in diabetes mellitus type 2. The rise of NCD is caused by two things, namely: risky dietary patterns and low physical activity which is included in the sedentary culture [8]. Developed countries in Europe and America have taken physical activity very seriously by incorporating physical education in school curricula from elementary to college. Because it is pointed out that the cause of obesity in children is mainly due to a lack of movement, and even WHO predicts that more than $60 \%$ of the human population in the world is not active enough [9].

The description of the level of physical fitness and obesity is an indicator of the success rate of physical education in schools, especially in elementary schools, so that this article will discuss the success rate of physical education in schools in terms of the physical fitness level of students in elementary schools in Buleleng District, Buleleng Regency, Bali.

\section{RESEARCH METHODOLOGY}

This research is a quantitative descriptive study, the stages consist of: 1) preparing a physical fitness test instrument (TKJI), 2) preparing a tool for measuring obesity by calculating the Body Mass Index (BMI), 3) collecting data such as: physical fitness data and BMI data. students, and 4) planning components and indicators to measure the results of the analysis.

The population in this study were elementary school students in Buleleng district with a total of 14,174 students spread across 82 elementary schools. Of the 14,147 population in this study, as many as 120 people were used as samples taken by random sampling technique, namely: where 4 schools were used as samples with the number of students of each school used as a sample of 30 people. This research was conducted from April to November 2020.

The data collection technique used was documentation study and test. Data collection activities using techniques according to the type of instrument used are as follows: 1) Documentation study, used to capture data in written documents that indicate a relationship with learning problems and see student activity in learning. Documentation studies are also used to help complete the correct data and the techniques used in the review and analysis and interpretation of the result documents can be used as data sources, 2) tests and measurements are used to determine the level of physical fitness and obesity of students.

\section{RESULTS AND DISCUSSION}

From the results of the data analysis, the students 'physical fitness levels were as follows: 1) as many as 3 people or $2.5 \%$ of the students' physical fitness levels were in the very low category; 2) as many as 45 people or $37.5 \%$ of the students' physical fitness levels are in the low category; 3) as many as 50 people or $41.67 \%$ of the students' physical fitness levels are in the medium category; 4) as many as 19 people or $15.83 \%$ of the students' physical fitness levels were in the good category; and 5) as many as 3 people or $2.5 \%$ of the students' physical fitness levels are in the very good category. When viewed in diagrammatic form, it looks like in diagram 1 .

Diagram 1. Percentage of Students' Physical Fitness Level

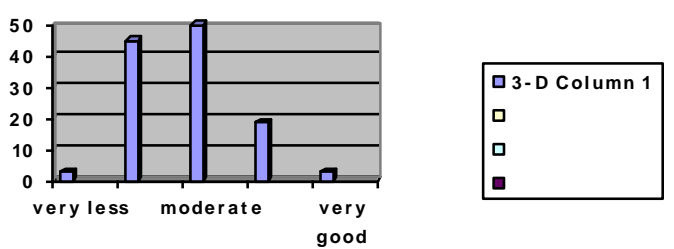

From the results of body mass index measurements, the following data were obtained: 1) the minimum height of the students was $114 \mathrm{~cm}$, the maximum height was $150 \mathrm{~cm}$, with the mean height was $134.36 \mathrm{~cm}$; 2) the minimum student body weight is $17 \mathrm{~kg}$, the maximum body weight is $51 \mathrm{~kg}$, with the mean body weight is $31.23 \mathrm{~kg}$; and 3 ) the minimum body mass index is 10.5 and the maximum is 28.99 with a mean of 17.11 . The test results of BMI obtained: 1) as many as 53 students or $44.17 \%$ are in the weight category thin; 2) as many as 32 students or $26.67 \%$ were in the thin to light category; 3 ) 2 students or $1.67 \%$ are in the normal 
category; and 4) 33 students or $27.5 \%$ are in the overweight category. If shown by a diagram, it looks like in diagram 2 .

Diagram 2. Student Body Mass Index
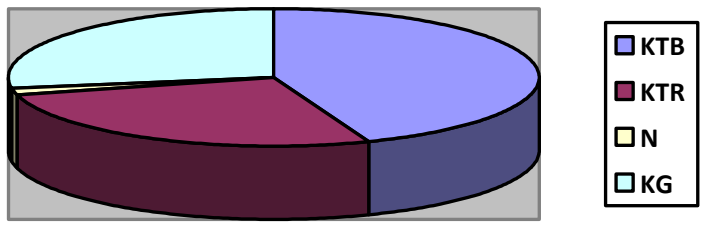

The results of the data analysis indicate that the physical education learning process in primary schools in Buleleng District is still ineffective. The ineffectiveness of the physical education learning process in primary schools in Buleleng District is very likely due to the facilities owned by the school, the ability of physical education teachers to design learning, lesson hours only once a week, and the influence of the very heavy onslaught of technology and social media resulting in sedentary living habits, resulting in obesity. The underlying cause of obesity and overweight is an energy imbalance between calories consumed and calories expended. Globally, there has been, an increase in the intake of energydense foods that are high in fat, and reduced physical activity due to the demands of jobs requiring population to sit continuously, changes in modes of transportation, and increasing urbanization. Changes in diet and physical activity patterns are the result of environmental and societal changes associated with development and a lack of supportive policies in sectors such as health, agriculture, transportation, urban planning, the environment, food processing, distribution, marketing, and education.

The learning process becomes an important part which determines the overall quality of education, and teachers have acentral role in improving the quality of learning process [10]. If physical education can be carried out well in schools, then of course it can be expected that a balanced human development will occur in terms of physical, mental, social, and spiritual aspects. Therefore, the essence of physical education is the educational process through providing learning experiences to students in the form of physical activities, playing, and exercising which are planned systematically to stimulate physical, organic, motor skills, thinking, emotional, social and moral growth and development. The provision of learning experiences is aimed at fostering, as well as forming, a life-long healthy and active lifestyle. This can happen very much depending on the ability of the physical education teacher to design learning that is more interesting, fun, and challenging for students to do activities. The role of physical education teachers is mainly seen in programing learning that is able to develop student activities according to their potential depends on the ability of physical education teachers to choose physical education methods [11]. The PE teacher has the role of facilitating students to carry out motion tasks that are appropriate to the level of student growth and development [12].

In the intensification of education as a lifelong human development process, the role of physical education is very important, which is to provide opportunities for students to be directly involved in various learning experiences through physical activities, play, and sports activities systematically. This is a medium to encourage the development of motor skills, physical abilities, knowledge and reasoning, appreciation of values (mental, emotional, spiritual, and social attitudes), as well as habituation to a healthy lifestyle which aims to stimulate balanced growth and development.

The learning process becomes an important part which determines the overall quality of education, and teachers have a central role in improving the quality of learning process [12]. Through Physical Education learning students will gain experiences that are closely related to pleasant personal impressions of various creative, innovative expressions, movement skills, physical fitness, healthy living patterns, knowledge and understanding of human movement, will also form positive personality [13].

Physical Education emphasizes aspects of education that are comprehensive (health, physical fitness, critical thinking skills, emotional stability, social skills, reasoning and moral action), which are the goals of education in general. Or specifically through physical education learning, students carry out activities in the form of games, and exercise (adjusted to children's growth and development) [14]. In fact, physical education is a very broad field of study. His point of interest is the improvement of human movement. More specifically, physical education is concerned with the relationship between human movement and other areas of education: the relationship of the development of the physical body to the mind and spirit. It is its focus on the influence of physical development on the area of growth and development of other aspects of the human being which makes it unique. There is no other single field such as physical education which is concerned with the total development of humans [15].

\section{CONCLUSION}

Based on the results of data analysis and discussion, it can be concluded that the implementation of the Physical Education learning process in elementary schools in Buleleng District has not been effective, this can be seen from the physical fitness level of students (only $18.33 \%$ are in the good category) and the body mass index is only $1,67 \%$ are in the normal category.

\section{IMPLICATION AND RECOMMENDATION}

Based on these conclusions it is suggested that physical education teachers in primary schools in Buleleng District be able to better design physical education learning by modifying the tools needed so that learning becomes more enjoyable so that students will be interested in doing physical activities outside physical education lesson hours in school. 


\section{ACKNOWLEDGMENT}

Our appreciation and gratitude are for the chairman of the research institute of Universitas Pendidikan Ganesha, who had given the funds for this research, as well as the Physical Education teachers in Buleleng District, Faculty of Sport, Universitas Pendidikan Ganesha for their support and motivation.

\section{REFERENCES}

[1] Purwadi, Ade Mardiana, Wira Indra Satya, Pendidikan Jasmani dan Olahraga, (Jakarta: Universitas Terbuka, 2008), h. 1.4

[2] Sukintaka. 2004. Teori Pendidikan Jasmani, Filosofi Pembelajaran dan Masa Depan. Bandung: Nuansa.

[3] Mutohir, Toho Cholik dan Ali Maksum. 2007. Sport Development Indeks, Alternatif Baru Mengukur Kemajuan Pembangunan Bidang Olahraga. (Konsep, Metodologi dan Aplikasi). Jakarta: PT INDEKS.

[4] I K Yoda. "The Development of Cooperative Learning Model Based on Local Wisdom of Bali for Physical Education, Sport and Health Subject in Junior High School" $1 \mathrm{st}$ Annual Applied Science and Engineering Conference IOP Publishing IOP Conf. Series: Materials Science and Engineering 180 (2017) $012166 \quad$ doi:10.1088/1757$899 \mathrm{X} / 180 / 1 / 012166$.

[5] WHO, 2020 dalam https://www.who.int/healthopics/obesity\#tab=tab_1 (diakses 29 Oktober 2020

[6] Depkes RI. 2013. Riset Kesehatan Dasar (Riskesdas). Badan Penelitian dan Pengembangan Kesehatan. Jakarta: Departemen Kesehatan Republik Indonesia.

[7] Pemina dalam http://www.pesona.co.id/sehat/ kesehatan /cegah. obesitas.pada.anak/002/002/87, (diakses 5 Januari 2020)

[8] Dwiyogo, Wasis D. 2009. Olahraga dan Pembangunan. Malang: Wineka Media.

[9] Ken Green. 2008. Understanding Psysical Education. Sage Publication Ltd, London ECIY ISP

[10] Muhson A, Lestari B, Supriyanto, and Baroroh K, 2014. A practice and aplicative Developmental Software Analysis for questions, Jurnal Ilmu Pendidikan, Jilid 20, Vol. 4, No.: 2. pp. 207-216.

[11] I Ketut Yoda, I Ketut Budaya Astra. 2019. The Effect of Reciprocal Learning Methods Assisted Feedback Visual on Learning Students Learning Outcomes in Junior High School and High School. 1st International Conference on Education, Social Sciences and Humanities (ICESSHum 2019), Published by Atlantis Press, This is an open access article under the CC BY-NC license (http://creativecommons.org/licenses/by-nc/4.0/) Volume 335 pp. 187193.

[12] Made Agus Wijaya, I Nyoman Kanca, I Ketut Yoda. 2019. Optimizing Sport Values Through Character-Based Motion Cards in Elementary School, 4th International Conference on Sport Science, Health, and Physical Education (ICSSHPE 2019), Published by Atlantis Press, Advances in Health Sciences Research, volume 21, pp.133-135.

[13] Freeman, William H, 6th ed. 2001. Physical Education and sport in a changing society. Boston: Allyn \& Bacon.

[14] Chatrine Himberg, Gayle E. Hutchinson, John M. Roussell. 2003. Teaching Secondary Physical Education, Preparing Adolescients to Be Active for Life. Human Kinetics: United States of America.

[15] Cavill, N., Biddle, S. J. H., \& Sallis, J. F. 2001. Health Enhancing Physical Activity for Young People: Statement of the United Kingdom expert consensus cnference. Pediatric Exercise Science. 